\title{
SUBLETHAL TOXICITY TESTS OF MERCURY (Hg) TO NILEM FISH (Osteochilushasselti) GILLS TISSUE DAMAGE
}

\author{
AsrulSahriSiregar ${ }^{1}$,NormanAriePrayogo ${ }^{1}$, Emyliana Listiowati ${ }^{1}$, Mahendro Santoso ${ }^{1}$, Indra \\ Gumay Yudha ${ }^{2}$,Tri WahyuniSholehah \\ ${ }^{1}$ ProgramStudiManajemenSumberdayaPerairan,Fak.PerikanandanIlmuKelautan, \\ UniversitasJenderalSoedirman, Indonesia \\ 2 JurusanPerikanandanIlmuKelautan,Fak.PerikanandanIlmuKelautan, UniversitasLampung, \\ Indonesia
}

\begin{abstract}
Industry development in Indonesia resulted in sewage and polluting heavy metals such as mercury $(\mathrm{Hg})$. These pollutants will be harm organisms that live at aquatic environment. Fish gills could be damage due to exposure by mercury. To know the influence of mercury's toxic against aquatic organisms by using toxicity test. An aquatic organism, which is usually used as toxicity test, is nilem fish (Osteochilushasselti). The objective of the study was to determine the value of LC50-96 hours in a toxicity test of nilem fish exposed to lead acetate; to determine the changes in the fish gill and to determine the concentration of lead mercury which causes tissue damage structure in the gills of nilem fish. The design used completely randomized design (CRD) with four concentrations ( $0 ; 0.08 ; 0.16$ and 0.24 ppm) and three replications. The objective of the study was sublethal toxicity test. Lethal toxicity concentration data were descriptive and data from sublethal toxicity test were One Way. The analysis showed that there were highest edema $10 \%$ and $17 \%$ on day 4 and 12 , the highest lamella fusion $35 \%$ and $59 \%$ on day 4 and 12 , the highest hyperplasia $45 \%$ and $54 \%$ on day 4 and 12 , and the highest necrosis the $65 \%$ and $80 \%$ on day 4 and 12 . It was concluded that the value of $L C_{50^{-}} 96$ hours in nilem fish (Osteochilushasselti) toxicity test was 0,3938 ppm; and damage of fish gill tissue changes started to occur in the lead mercury $(\mathrm{Hg})$ concentration of $0,08 \mathrm{ppm}$.
\end{abstract}


${ }^{1}$ Corresponding Author :asrul_sir@yahoo.com

\section{Introduction}

Indonesian industrial sector is growing in line with the advancement of science and technology. Increased development can reduce quality of the environment and public health, caused by the pollution. The source of pollution can be from industry, mining, agriculture, and other natural source from rock reaching river or sea, then polluting aquatic biota and it is environment.

Environmental order can be polluted or damaged by many things and most of all the cause is pollutants. One component of pollutants containing toxic substances such as heavy metals [1]. Heavy metal is a chemical element that has the potential to cause environmental pollution problems. One of them is mercury which is widely used for various industries such as gold mining. Alfian[2] stated that mercury is widely used in agriculture, industry and medical purpose. Mercury is used in agricultural sector for fungal and pest extermination such as fungicide, herbicide, and pesticide. Mercury is used in industrial sector for anti-fungi in paints and paper industry, and plastic synthetic. Mercury usage in medical sector for syphilis treatment, calomel $(\mathrm{HgCl})$ used for wound cleanser but not used anymore because it is known to be toxic, while in cosmetic commonly used for whitening cream [3].

Mercury and it is derivatives are the most harmful metal pollutant for aquatic biota and aquatic environments. One of the aquatic biota affected by mercury is fish. Fish can accumulate mercury in the form of methyl mercury, either through food or directly from the water. Based on Stokes and Wren [4] research, shown that $68-80 \%$ of mercury exist on environment were accumulated in fish body. Continuous accumulation of mercury metals will causing death on fish. This will endanger life of aquatic organism especially fish and damage the food chain in aquatic environment. The impact caused by the accumulation of mercury in fish shown on Dalimunthe[5] research, in BatangGadis River Mandaling Natal Regency, mercury $(\mathrm{Hg})$ accumulates in the body of mercury $(\mathrm{Hg})$ accumulates in the body of catten fish (Mystacoleucusmarginatus) which ranges from $0.00128-0,01097 \mathrm{ppm}$. It shows that mercury in river water has passed the threshold value of $0.001 \mathrm{mg} / 1$ based on Indonesian Republic Government Regulation No. 82 of 2001 on Water Quality Management and Water Pollution Control.

Research on mercury in mercury chloride compound itself has been done previously using carp (Cyprinuscarpio) with size 10-13 cm but still limited to liver damage. Based on research Destiany [6], that the concentration of $0.02 \mathrm{ppm}$ mercury chloride has caused damage to liver cells, while the LC50-96 hour value of $0.24 \mathrm{ppm}$. However information on the lethal and subletal effects of nilem fish has limited(20,21). Therefore, toxicity test of lethal and mercury subletal in freshwater fish that is nilem fish (Osteochilushasselti) need to be studied.

This study will examine the value of sub-lethal toxicity (LC50-96 hours) of mercury metals in nilem fish; How big is the influence of concentration and length of mercury $(\mathrm{Hg})$ exposure to the damage of gill tissue of nilem fish (Osteochilushasselti) at sub lethal condition (19). The benefit of this research is to provide information about histology of nilem fish gill (Osteochilushasselti) due to exposure to heavy metals mercury. In addition, this information can be used to determine the range of LC50-96 h values in the toxicity test of mercury-exposed nilem fish $(\mathrm{Hg})$ so as to determine the standard of mercury quality in the waters.

\section{Research Methods}


The research was focused on sub lethal toxicity test. Experimental method used with Completely Randomized Design (CRD). This study used nilem fish with length of 10-13 $\mathrm{cm}$. Mercury was used by diluting $\mathrm{HgCl} 2$ at determined concentration in 1 liter of water, after mercury dissolved it was mixed in to test medium of $30 \mathrm{~L}$ water, each treatment repeated 3 times.

In lethal toxicity test, the main parameter is percentage of fish mortality with series of mercury treatment. In sub lethal toxicity test, the main parameter observed is fish gill microanatomy with series of mercury treatment based on LC50-96 hour result. Observed supporting parameter was temperature, $\mathrm{pH}$, and dissolved oxygen.

\subsection{Media Preparation}

The research was undertaken at laboratory, 18 aquariums with a capacity of 50L were prepared, washed and dried expose those to the sunlight, then filled with $30 \mathrm{~L}$ of a mixture and dilution of mercury and water with different $\mathrm{Hg}$ concentration per treatment an then aerators installed. Nilem fish acclimated at 5 days, one day before used and during treatment periods fish were fastened. The size of nilem fish used is $10-13 \mathrm{~cm}$ and for evenness purpose the larger fish should not more than $1 \frac{1}{2}$ small fish [7].

\subsection{Sub Lethal Test}

Sub lethal test used 12 aquariums with capacity of 50L. Each was filled with 30L of test medium and 15 fish. Sub lethal observation was done by taking fish gill in 2 period of time $\left(4^{\text {th }}\right.$ and $12^{\text {th }}$ day) one of each treatment to observe fish's gill histology.

Microscopic observation ofnilem fish (Osteochilushasselti) gill histology done to gill's filament, compound microscope used at 40x10 magnification scale. The extend damage to the gill tissue of nilem(Osteochilushasselti) was analyzed based on gill structure changes in lamella edema in which the lamella epithelial cell release from the underlying tissue. Hyperplasia is the occurrence of abnormal increase of the total cells in lamella and fusion of lamella which is the loss of secondary lamella structure and filament damage.

\subsection{Physic and Chemical Parameter Measurement}

Measured parameter were temperature, $\mathrm{pH}$, and dissolved oxygen. Water physical and chemical quality was measured from designed treatment media.

\subsection{Research Time and Place}

The research was done from January until April 2015 at Faculty of Biology JendralSoedirman University, Microanatomy Laboratory Faculty of Veterinary, GadjaMada University, Yogyakarta, and Aquatic Research Management Laboratory Faculty of Fishery and Marine Culture JendralSoedirmanUniversityl, Purwokerto.

\subsection{Data Analysis}

Data obtained from the observation of tissue damage nilem fish (Osteochilushasselti) in the form of qualitative data. Percentage of gill tissue damage rate was analyzed descriptively and quantitatively based on the change of gill structure edema, hyperplasia, lamia fuse and necrosis. Gill tissue damage percentage calculation was done by observing 
gill lamella, at microscope with 400x magnifier. The result from damaged gill tissue analyzed with One Way ANOVA to determine concentration used damaging tissue or not.

\section{Results and Discussion}

\subsection{Test Medium Water Quality}

Water quality measured were physical and chemical parameters such as temperature, $\mathrm{pH}$ and dissolved oxygen. Temperature and $\mathrm{pH}$ measurement were done at the start, middle, and end of the research, dissolved oxygen measurement was done at start and end of the research. The purpose of measurement was to monitor water quality for nilem fish during the research. The result of parameter measurement can be seen at Table 1.

Table 1. Parameter measurement result

\begin{tabular}{lcc}
\hline Parameter & Value & $\begin{array}{c}\text { Quality } \\
\text { Standard }\end{array}$ \\
\hline $\begin{array}{l}\text { Temperature } \\
\left({ }^{\circ} \mathrm{C}\right)\end{array}$ & $25-29$ & $20-30$ \\
\hline $\mathrm{pH}$ & $7,40-8,56$ & $7-8,5$ \\
\hline $\mathrm{DO}(\mathrm{mg} / \mathrm{L})$ & $4,8-7,8$ & $5,4-6,2$ \\
\hline
\end{tabular}

Based on the result, temperature, $\mathrm{pH}$, and dissolved oxygen during the research were still in tolerated value for fish to live.

\subsection{Sub-lethal Toxicity Test}

The sub-lethal test was done after lethal toxicity test $\left(\mathrm{LC}_{50-96}\right)$. The concentration for sub-lethal test were $0 \%, 20 \%, 40 \%$ and $60 \%$. The result from $\mathrm{LC}_{50^{-} 96}$ indicates that higher the concentration of mercury causing more severe gill damage.

According to Palar [1], the process of mercury entering gill is mercury with other metals ion will form ion that solublein fats. The metal ions that can soluble in fats can penetrate gill cell membrane and enter the gill. Connel[8] state that toxic element intake on the aquatic organism can happen by 3 methods: (1) Respiration, (2) Contact with toxic element, and (3) Feed, digested water particle. Dissolved toxic and organic compound causing irritation on gills and gills lamella, this disturbed the respiration process.

The level of damaged gill tissue $<30 \%$ means light damage. The level of damaged gill tissue $30 \%-70 \%$ means moderate damage. The level of damaged gill tissue $>70 \%$ means severe damage.

The damage of nilem gill tissue exposed to mercury for 4 and 12 days with different concentration show on figure 3. The lightest damage is edema. Edema is the first phase of gill degeneration showed by swelling. The edema damage presentation is shown on figure 1 . 


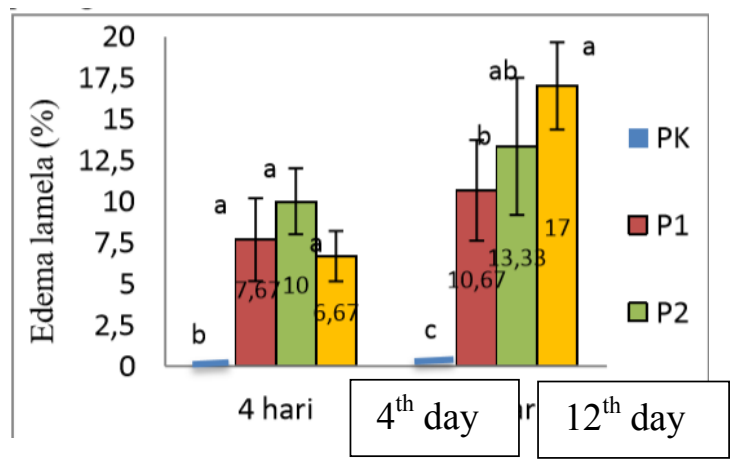

Fig 1. The edema damage presentation in day 4 and day 12

The damage value caused by edema show significant difference $(\mathrm{P}<0,05)$ on treatment concentration $0 \mathrm{mg} / \mathrm{L}$ to $0,08 \mathrm{mg} / \mathrm{L}, 0,16 \mathrm{mg} / \mathrm{L}$ and $0,24 \mathrm{mg} / \mathrm{L}$ in day 4 , but in day 12 only on treatment $0 \mathrm{mg} / \mathrm{L}$ to $0,08 \mathrm{mg} / \mathrm{L}$ and $0,24 \mathrm{mg} / \mathrm{L}$ that show significant difference, treatment concentration $0,16 \mathrm{mg} / \mathrm{L}$ did not show significant difference $(\mathrm{P}>0,05)$. The significant difference $(\mathrm{P}>0,05)$ means that mercury treatment concentration is affecting edema presentation on nilem fish gill. Robert [9]states that edema on lamella caused by contact with high concentration chemicals that mainly metals. Edema will inhibit gas diffusion efficiency and causing death on organism. Gas diffusion is inhibited because of narrowing secondary gill lamella.

Mercury concentration of $0,16 \mathrm{ppm}$ on day $4^{\text {th }}$ observation showed high edema. Likewise, when the observation on the 12th day of $0.24 \mathrm{ppm}$ treatment showed high edema. This is because on the 4th day observation the mercury concentration of $0.24 \mathrm{ppm}$ has not affected the edema of the gills of nilem fish, but the longer the gill is exposed to heavy metals mercury then there is an increase of edema in the gill tissue, as happened during the observation of the 12th day of treatment $0.24 \mathrm{ppm}$ of mercury has an effect on edema. This is supported by Dalimunthe [5] study which states that edema with $30-70 \%$ of field extent also occurs in Cencen fish (Mystacoleucusmarginatus) taken from Sungai BatangGadis Kalimantan, with a content of $\mathrm{Hg}$ in water of $0.5 \mathrm{ppm}$.

The other damages that occur are hyperplasia. Hyperplasia occurs in the treatment of $0.08 \mathrm{ppm}, 0.16 \mathrm{ppm}$ and $0.24 \mathrm{ppm}$. Hyperplasia is excessive tissue formation due to the increase in the number of cells [9]. The percentage of hyperplasia in the gill tissue of nilem fish was observed on the 4th and 12th days showed in figure 2. 


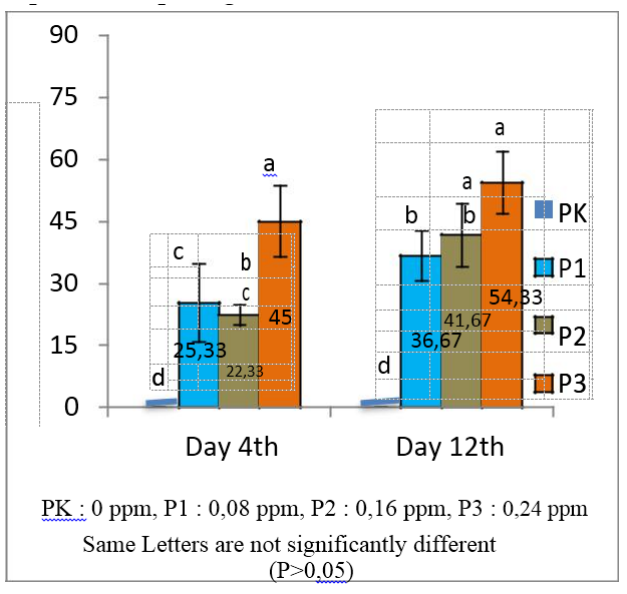

Fig 2.Percentage of hyperplasia on day 4 th and 12 th.

The 4th day the average of hyperplasia at the treatment of $0.08 \mathrm{ppm}$ and $0.24 \mathrm{ppm}$ showed significant difference $(\mathrm{P}<0.05)$ to the control, whereas in the treatment of 0.16 $\mathrm{ppm}$ there was no significant difference $(\mathrm{P}>0,05)$ to the $0.08 \mathrm{ppm}$ treatment. The 12 th day, the $0.08 \mathrm{ppm}$ and $0.24 \mathrm{ppm}$ treatments showed significantly different values $(\mathrm{P}<0.05)$ to the control, while the $0.16 \mathrm{ppm}$ treatment showed no significant difference $(\mathrm{P}>0.05)$ treatment $0.24 \mathrm{ppm}$. Significantly different concentration $(\mathrm{P}<0.05)$ could be interpreted that the percentage value of hyperplasia in the gills of nilem fish was influenced by the treatment of mercury concentration. Concentrations were not significantly different $(\mathrm{P}>$ 0.05) can be interpreted that the treatment of concentration does not affect the percentage value of hyperplasia in the gills of nilem fish.

The observation of the 4 th and 12th days the gill at the highest treatment $(0.24 \mathrm{ppm})$ showed the greatest hyperplasia. This is because irritated nilem fish gill due to the large content of heavy metals mercury and characterized by an increase in the number of mucus cells in the base lamella. Concentration does not affect the percentage value of hyperplasia in gill nilem fish.

The addition of the number of secondary lamella epithelium causes the secondary lamella to become enlarged and coincident, the result between secondary lamella to stick together and unite. This makes the gill lamella appear larger than normal and the gill is no longer clearly visible difference between the primary and secondary lamella [10]. This is in accordance with the research of Yuniar et al., [11], that on the observation of the 10th day of $\mathrm{Hg}$ treatment of $0.15 \mathrm{ppm}$, the (Oreochromisniloticus) gill experienced the greatest hyperplasia. Hyperplasia makes the gill lamella appear larger than normal and the gill is no longer clearly visible between the primary lamellae and the secondary lamellae.

The 4 th-day observation at the lowest treatment $(0.08 \mathrm{ppm})$ had slight hyperplasia. This is because at a concentration of $0.08 \mathrm{ppm}$ in a time of 4 days exposure has not caused significant hyperplasia symptoms, in addition, $0.08 \mathrm{ppm}$ treatment did not cause hyperplasia damage because it has become fusion lamella. This is supported by a statement from Robert [9] that hyperplasia occurs at a lower irritation level and is usually accompanied by an increase in the number of mucus cells in the lamella base and results in lamella fusion. 


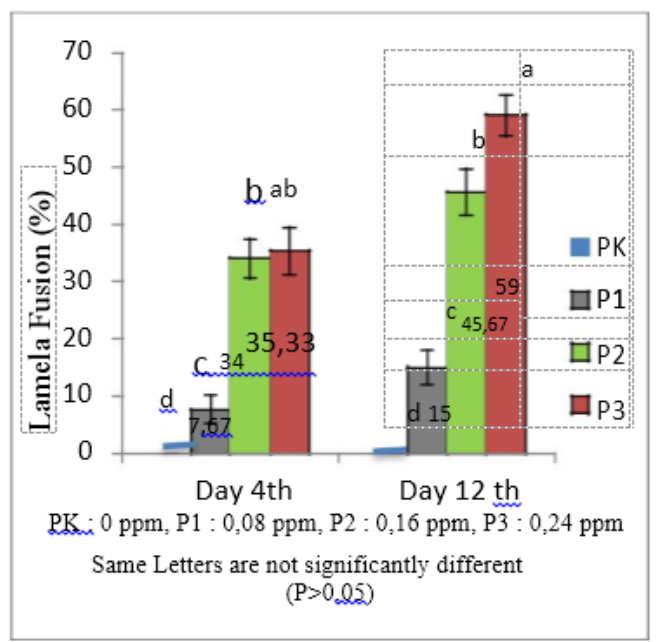

Fig 3.Percentage of Lamella Fusion on day 4th and 12th.

The next damage is the fusion of lamella found in the three treatments concentration, $0.08 \mathrm{ppm}, 0.16 \mathrm{ppm}$ and $0.24 \mathrm{ppm}$. The highest lamella fusion on day 4 th was found in the treatment of $0.24 \mathrm{ppm}$, which ranged from $35.33 \%$, then the lowest average was shown in the control treatment which ranged from $0 \%$. While on the 12 th day, the highest lamella fusion was found in the treatment of $0.24 \mathrm{ppm}$, which is about $59 \%$ and the lowest average was shown at $0 \mathrm{ppm}$. This shows the treatment of $0.24 \mathrm{ppm}$ to moderate damage that is about $30-70 \%$ of the field width of view.

Lamella fusion in nilem fish gill due to mercury metal tends to increase at treatment $0.08 \mathrm{ppm}, 0.16 \mathrm{ppm}$ and $0.24 \mathrm{ppm}$. The highest lamella fusion was found in the treatment of $0.24 \mathrm{ppm}$, ie on the 4 th and 12 th day observations with values of $35 \%$ and $59 \%$. On day 4, lamella fusion of $0.08 \mathrm{ppm}$ and $0.16 \mathrm{ppm}$ mercury treatment showed significant differences in control treatment $(\mathrm{P}<0.05)$, whereas in the treatment of $0.24 \mathrm{ppm}$ did not show any significant difference $(\mathrm{p}>0.05)$ to the treatment of $0.16 \mathrm{ppm}$. On day 12 , lamella fusion of mercury treatment $0.08 \mathrm{ppm}, 0.16 \mathrm{ppm}$ and $0.24 \mathrm{ppm}$ showed significant differences in control treatment $(\mathrm{P}<0.05)$. A significantly different concentration $(\mathrm{P}<0.05)$ can be interpreted that the concentration treatment does not affect the percentage value of lamella fusion in the gills of nilem fish. Concentrations that were not significantly different $(\mathrm{P}>0.05)$ could be interpreted that the concentration treatment did not affect the percentage value of lamella fusion in the nilem fish gill.

The 4th and 12th day observations at the highest mercury treatment $(0.24 \mathrm{ppm})$ experienced the greatest lamella fusion. This is caused by the amount of edema at a concentration of $0.24 \mathrm{ppm}$ which can trigger the occurrence of fusion of lamella that attaches two parts of secondary lamella. This is on accordance to the Dalimunthe[5] study that looked at cencen fish (Mystacoleucusmarginatus) gill histology that occurred in a primary lamella fusion of $30 \%$ of the viewing area of $\mathrm{Hg}$ concentration of $0.04 \mathrm{ppm}$.

Lamela fusion is caused by gill organs in contact with mercury ions, so the gills release mucus for protection against mercury toxicity, but the resulting mucus closes the lamella surface of the gill so that the exchange of $\mathrm{O} 2$ and $\mathrm{CO} 2$ is inhibited. According to Sukarni et al., [12] statement that excess mucus is one of the mucous gland's responses to protect gills from mercury, but if the resulting mucus is excessive it will be negative for the fish so that oxygen uptake from the water will become obstructed.

The observations of the 4th and 12th days of the nilem fish gill at the lowest treatment concentration $(0.08 \mathrm{ppm})$ experienced slight lamella fusion. This is because at these 
concentrations, nilem fish not releasing much mucus out of mucus cells that can lead to increased lamella fusion. This is supported by a statement from Mulyani et al. [13] that lamela fusion can occur because the mucus cells in the lamella are increased in number resulting in the fusion between the secondary lamella.

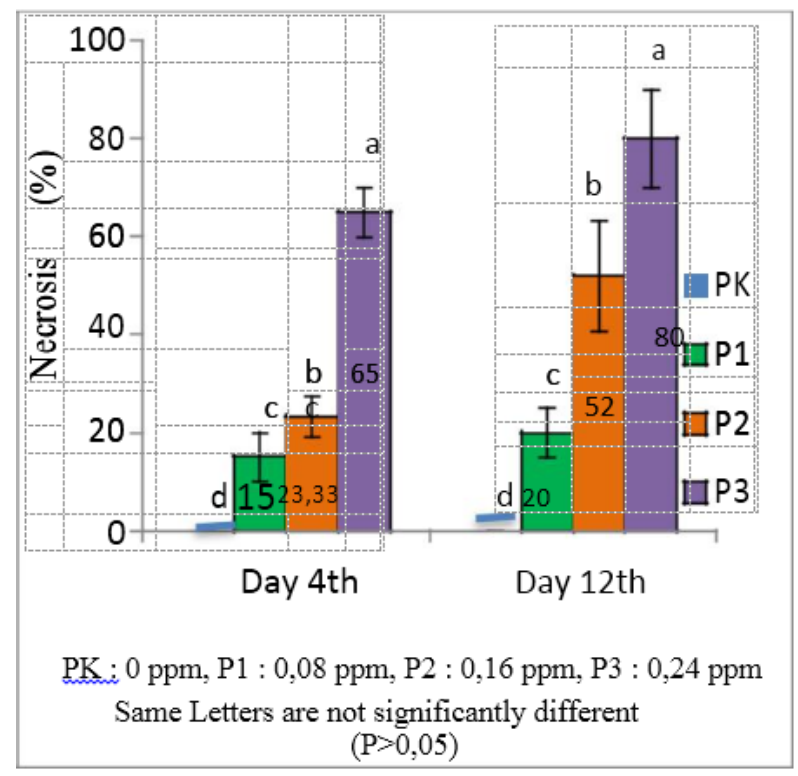

Fig 4. Percentage Necrosis on day 4th and 12th.

Other damage to the gills of nilem fish is necrosis. Necrosis is cell death that occurs due to hyperplasia and excessive secondary lamela fusion, so that the gill tissue is not intact anymore or in other words necrosis occurs accompanied by the death of a biota. According to Plumb [14] necrosis is characterized by the presence of death of cells or tissues accompanying cell degeneration in each necrosis of the gill tissue of the observed nilem on the 4 th and 12 th days can be seen in Figure 4.

The necrosis percentage value on day 4 showed significant difference $(\mathrm{P}<0.05)$ in 0.08 ppm and $0.24 \mathrm{ppm}$ for $0 \mathrm{ppm}$ (control) treatment concentration, while $0.16 \mathrm{ppm}$ treatment did not show the significant difference $(\mathrm{P}>0,05)$ to $0,24 \mathrm{ppm}$ treatment. A significantly different concentration $(\mathrm{P}<0.05)$ can be interpreted that the concentration treatment does not affect the percentage value of necrosis in nilem fish gill. Concentrations that were not significantly different $(\mathrm{P}>0.05)$ could be interpreted that the treatment of concentration did not affect the value of percentage of necrosis in gill nilem fish.

Necrosis on the nilem fish gill tends to increase at $0.08 \mathrm{ppm}, 0.16 \mathrm{ppm}$ and $0.24 \mathrm{ppm}$. The observation in day 4 th and day 12 th the gill at the highest treatment concentration $(0.24$ ppm) experienced the greatest necrosis.

This is because the concentration of mercury in the water is too high and there is continuous absorption of mercury ions into the gill tissue. Exposure to heavy metals with high doses can cause damage to gill cells, because the gill tissues are the first that have contact with heavy metals in the fish body [10]. This is supported by the Nirmala [15] study, that with $0.3 \mathrm{ppm}$ mercury dose during 72 hours exposure on gold fish (Cyprinuscarpio) seen a lot of damage to the lamella suffering from necrosis $(>70 \%)$. The necrosis seen in these observations proves that fish contaminated by heavy metals $\mathrm{Hg}$ inhibit the oxygen for cell growth and development due to the destruction of the fish's 
circulatory system where the blood that carries the nutrient throughout the body is disrupted, resulting in deaths in the gill tissue.

The condition gill on the 12th day at mercury treatment concentration of $0.24 \mathrm{ppm}$ experienced a severe level of damage compared to $0.08 \mathrm{ppm}$ and $0.16 \mathrm{ppm}$. The shape of the gill lamella was destroyed and deformed severely. Most gill epithelial are detached from the organs. Before deformation occurs, the epithelium is edematous. This is in accordance to the study of Yuniar et al. [11] that mercury toxicity of $0.15 \mathrm{ppm}$ in Nile fish (Oreochromisniloticus) at day $20^{\text {th }}$ exposure, gill conditions experienced very severe necrosis levels when compared with day 4 th and day $10^{\text {th }}$ exposure.

\subsection{Nilem Fish Gill Destruction}

The degree of histologic symptoms of gill damage observed included edema, hyperplasia, lamella fusion and necrosis. The observed level of gill tissue damage from 3 treatments $(0.08 \mathrm{ppm}, 0.16 \mathrm{ppm}$ and $0.24 \mathrm{ppm})$ can be seen in Figures 5, 6 and 7 .

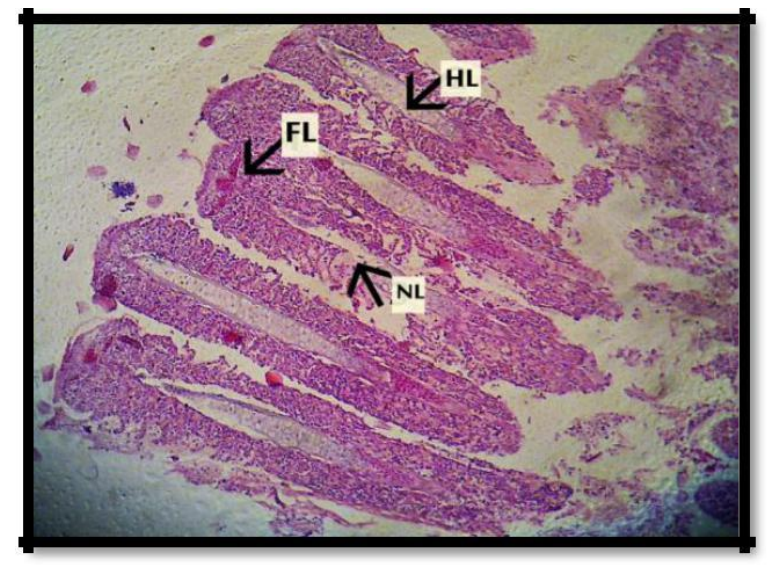

Fig 5. The histologic features of nilem fish gill (Osteochilushasselti) $\mathrm{Hg}$ concentration $0.08 \mathrm{ppm}$ with 400x magnification. FL: Secondary lamella fusion, HL: Primary lamella hyperplasia, NL: Secondary lamella necrosis.

The effect of mercury with concentrations of 0.08 and $0.16 \mathrm{ppm}$ (Figure 5) resulted in damage to the structure of gill tissue in the form of lamella fusion. Lamella fusion is characterized by the presence of fusion (attachment) between the secondary lamella due to secondary lamella epithelial hyperplasia. At this concentration there is an increase in damage from the concentration of $0.08 \mathrm{ppm}$, this is in accordance with the statement of Lu [16] which states that the higher the concentration of a toxic material in the water then the damage will occur more and more. Excessive hyperplasia and edema at a concentration of $0.08 \mathrm{ppm}$ may cause lamella fusion. Lamella fusion is the attachment of two parts of the secondary lamella. In addition, lamella fusion is also caused by the excessive mucus in the gills that will close the secondary lamella. This excess mucus is one of the mucous gland's responses to protect the gills from mercury, but if the resulting mucus is excessive it will be negative so that oxygen uptake from water will be inhibited [17]. 


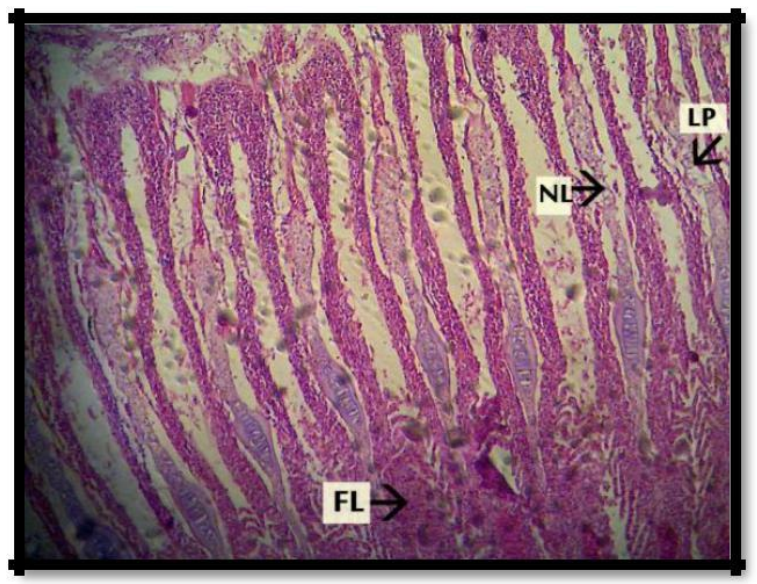

Fig 6. Histologic features of nilem fish gill (Osteochilushasselti) $\mathrm{Hg}$ concentration $0.16 \mathrm{ppm}$ with 400x magnification. LP: Bent Primary Lamella, FL: Secondary lamella fusion, NL: Primary lamella necrosis.

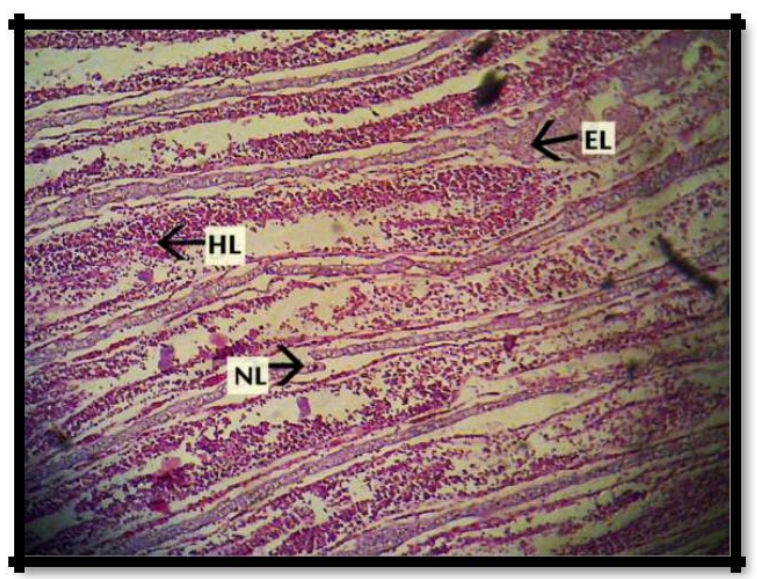

Fig 7. Histologic features of gill fish nilem (Osteochilushasselti) $\mathrm{Hg}$ concentration $0.24 \mathrm{ppm}$ with 400 xmagnification. NL: Primary lamella necrosis, HL: Primary laryngeal hyperplasia, EL: Primary lamella edema.

The description of the structure of the gill tissue at concentrations of $0.16 \mathrm{ppm}$ and 0.24 ppm (Fig. 6 and Fig. 7) contained edema and is still in moderate criteria [18]. Other damages seen at concentrations of $0.24 \mathrm{ppm}$ are hyperplasia. Hyperplasia is excessive tissue formation due to the increase in the number of cells. Hyperplasia occurs with the addition of the number of secondary lamella epithelium so that the secondary lamella is enlarged and coincided, consequently between secondary lamella stick together and fused. This makes the gill lamella appear larger than normal and the gill is no longer clearly visible difference between primary and secondary lamellae. The presence of hyperplasia will reduce the surface area of contact between the gill tissue with oxygen, resulting in the gas and ion exchange process during respiration is inhibited [15]. 


\section{Conclusions}

Based on the results and discussion it can be concluded that the sub-lethal toxicity effect on the condition of nilem fish gill tissue (Osteochilushasselti), there is edema 10\%, 45\% hyperplasia, $35 \%$ lamella fusion and necrosis of $65 \%$ on day 4 . While on the 12 th day, there was edema of $17 \%, 54 \%$ hyperplasia, $59 \%$ lamella fusion and necrosis by $80 \%$. The longer the mercury exposure time and the higher the mercury concentration exposed to the nilem fish, indicating an increase in gill tissue damage. Based on the results of this study suggested further research on gill tissue damage due to the influence of mercury in living organisms with longer exposed time or with varying mercury concentrations. The use of other heavy metals of the same concentration in this study may also be applied, so that it can be used as a comparison.

\section{Reference}

1 Palar, H. PencemarandanToksikologiLogamBerat. (Jakarta, RinekaCipta, 2008)

2 Alfian, Z. PidatoPengukuhanJabatan Guru BesarTetapdalambidangIlmu Kimia AnalitikpadaFakultasMatematikadanIlmuPengetahuanAlam.(Universitas Sumatra Utara, Medan,2006)

3 Widowati, W. EfekToksikLogam. (Andi, Yogyakarta, 2008)

4 Stokes, P. M., dan Wren, C. SCOPEJournal.16, 255-277 (1987)

5 Dalimunthe, L.S. Skripsi.(FakultasPertanian,Universitas Sumatera Utara, 2010)

6 Destiany, M. Skripsi. (UniversitasNegeriSemarang, Semarang,2007)

7 APHA (American Public Health Association).Standard Method for TheExamination of Water and Waste Water.21 th ed.(American Publik Health AssociatoinInc, New York,2005)

8 Connel,D.W.BioakumulasiSenyawaXenobiotik. (Jakarta, UI Press,1995)

9 Robert, R.J. Fish Pathology. USA: W. B.Saunders.Finney, D.J. ProbitAnalisis;A StatisticalTreatment Of The Sigmoid Response Curve, (Cambridge at the University Press, 2009)

10 Rennika, Aunurohim, Nurlita, A. JurnalSainsdanSeniPomits. 2, 132-137 (2013)

11 P. Sukardi, Hana, H., Prayogo, N.A., Harisam, T., Winanto, T. ActaScientiarum Animal Sciences 40,e38335. (2018)

12 Sukarni, M., danNursyam.JurnalExpo Life Sci.2, 6-12 (2012)

13 Siregar, A.S., Prayogo, N.A. European Zoological Journal 84(1), pp. 436-443 (2017)

14 Plumb, J.A. 6,118-121 (1994)

15 Nirmala, K. JurnalAkuakultur Indonesia. 11, 38-48 (2007)

16 Lu,C.F.ToksikologiDasar. (Jakarta,Universitas Indonesia, 2008)

17 Lagler, K.F. Bardach, J. E, Miller, R.R, Passino, D.R.M. Ichtiology. Second Edition. (New York, John Wiley and Sons, 1997)

18 andjung, S.D. Paper presented in theInternational Seminar on Human Ecology, Tourism, and Sustainable Development (Denpasar, 1982 
19 N.A Prayogo, g.e. wijayanti, murwantoko, m. Kawaichi and p. Astuti.8(6) : 591-597. (2012)

20 N.A Prayogo, G.E. Wijayanti, I. Sulistyo, P. Sukardi. Biodiversitas.17, 523-530 (2016)

21 N.A. Prayogo, A. Siregar, P. Sukardi. Turkish journal fishery and aquatic science. 16, 1003-1009 (2016) 